\title{
Impact of Consciousness Energy Healing Treatment on the Physicochemical and Thermal Properties of Magnesium Gluconate
}

\author{
Alice Branton $^{1}$, Snehasis Jana ${ }^{2, *}$ \\ ${ }^{1}$ Trivedi Global, Inc., Henderson, Nevada, USA \\ ${ }^{2}$ Trivedi Science Research Laboratory Pvt. Ltd., Bhopal, India \\ Email address: \\ publication@trivedieffect.com (S. Jana) \\ ${ }^{*}$ Corresponding author
}

\section{To cite this article:}

Alice Branton, Snehasis Jana. Impact of Consciousness Energy Healing Treatment on the Physicochemical and Thermal Properties of Magnesium Gluconate. American Journal of Chemical Engineering. Vol. 5, No. 4, 2017, pp. 64-73. doi: 10.11648/j.ajche.20170504.13

Received: May 20, 2017; Accepted: May 31, 2017; Published: July 12, 2017

\begin{abstract}
Magnesium gluconate is usually used as a dietary supplement for the prevention and treatment of hypomagnesemia as well as to maintain the overall quality of life. The present study was designed to evaluate the impact of The Trivedi Effect ${ }^{\mathbb{}}$-Energy of Consciousness Healing Treatment on the physicochemical and thermal properties of magnesium gluconate using PXRD, PSA, DSC, and TGA/DTG analysis. Magnesium gluconate was divided into two parts - one part was control (without Biofield Energy Treatment), while another part was treated with Energy of Consciousness Healing Treatment (The Trivedi Effect ${ }^{\mathbb{B}}$ ) remotely by the renowned Biofield Energy Healer, Alice Branton and defined as Biofield Energy Treated sample. The PXRD analysis showed that the relative peak intensities and crystallite sizes of the characteristic diffraction peaks in the treated sample were significantly altered from $-73.55 \%$ to $17.21 \%$ and from $-14.28 \%$ to $125.11 \%$, respectively compared with the control sample. The average crystallite size was significantly increased by $19.29 \%$ in the treated sample compared to the control sample. The particle size values at $\mathrm{d}_{10}, \mathrm{~d}_{50}, \mathrm{~d}_{90}$, and $\mathrm{D}(4,3)$ of the treated sample was significantly increased by $2.03 \%, 70.92 \%, 142.25 \%$, and $95.42 \%$, respectively compared with the control sample. Thus, the surface area of treated sample was significantly decreased by $21.34 \%$ compared to the control sample. The melting point of the Biofield Energy Treated sample $\left(170.16^{\circ} \mathrm{C}\right)$ was decreased by $0.19 \%$ compared the control sample $\left(170.48^{\circ} \mathrm{C}\right)$. The latent heat of fusion in the treated sample was increased by $3.11 \%$ compared to the control sample. The TGA analysis exhibited three steps thermal degradation and the total weight loss of the treated sample was increased by $0.29 \%$ compared to the control sample. The maximum thermal degradation temperatures $\left(\mathrm{T}_{\max }\right)$ of the $1^{\text {st }}$ and $2^{\text {nd }}$ peaks were decreased by $2.86 \%$ and $1.97 \%$, respectively, while $2^{\text {nd }}$ and $3^{\text {rd }}$ peaks were increased by $1.14 \%$ and $0.94 \%$ respectively, in the treated sample compared to the control sample. The thermal analysis revealed that the thermodynamic stability of the treated sample was changed compared with the control sample. The Energy of Consciousness Healing Treatment might produce a crystalline polymorphic form of magnesium gluconate, which could show better powder flowability and appearance with altered thermal stability compared to the untreated sample. Hence, Biofield Energy Treated magnesium gluconate would be advantageous in designing better nutraceutical/pharmaceutical formulations that might provide better therapeutic responses against inflammatory diseases, immunological disorders, cancer, diabetes mellitus, stress, aging, etc.
\end{abstract}

Keywords: Biofield Energy Healing Treatment, The Trivedi Effect ${ }^{\circledR}$, Magnesium Gluconate, PXRD, Particle Size, Surface Area, DSC, TGA/DTG

\section{Introduction}

Magnesium gluconate is a classical nutraceutical / pharmaceutical solid compound used for the source of magnesium, the important essential element for many enzymes, DNA, RNA and protein synthesis in the human body [1-3]. Magnesium gluconate is widely used for 
hypomagnesemia and for the prevention and treatment of several diseases, such as inflammatory diseases, immunological disorders, cancer, diabetes mellitus, allergies, arrhythmias, septic shock, asthma, gestational hypertension, acute myocardial infarction, preeclampsia, eclampsia, oxidative stress induced ischemia/reperfusion injury, hearing loss, etc. [4-10]. It is also used as a potent antioxidant agent, oral tocolytic agent, neuroprotective, and skin-tightening antiaging cosmetic composition [11-13]. It is a physiologically acceptable salt which provide the highest level of magnesium among the other commercially available magnesium salts $[4,5,14]$.

Since from ancient times, many different cultures, religions, and systems recognized a living force that preserves and inhabits every living organism. This force is the source of 'life' and has been called various names, such as prana by the Hindus, $k i$ by the Japanese, and $q i$ or chi by the Chinese. This is believed to co-relate with the soul, spirit, and mind. This imaginary vital force has been scientifically assessed and is now considered the Bioenergetics Field. The Biofield Energy is a dynamic electromagnetic field surrounding the human body, resulting from continuous movement of the electrically charged particles (ions, cells, etc.) inside the body and it continuous discharges the electromagnetic waves in the form of bio-photons. This electromagnetic wave can freely flow between the human and environment [15]. Thus, a human has the capability to harness energy from the "universal energy field", and transmit it to any living organism(s) or nonliving object(s) around the globe. The object or recipient always receives the energy and responds in a useful way. This process is known as Biofield Energy Healing Treatment [16, 17]. Biofield (Putative Energy Field) based Energy Therapies are used worldwide to promote health and healing. The National Center of Complementary and Integrative Health (NCCIH) has recognized and accepted Biofield Energy Healing as a Complementary and Alternative Medicine (CAM) health care approach in addition to other therapies, medicines and practices such as natural products, yoga, Tai Chi, Qi Gong, meditation, massage, special diets, homeopathy, guided imagery, acupuncture, acupressure, hypnotherapy, movement therapy, pilates, mindfulness, rolfing structural integration, Ayurvedic medicine, traditional Chinese medicines, naturopathy, essential oils, aromatherapy, Reiki, healing touch, cranial sacral therapy, applied prayer, etc. [18]. The Trivedi Effect ${ }^{\circledR}$ has gained the importance in several fields include material science $[19,20]$, organic compounds [21, 22], agricultural [23, 24], microbiology [25, 26], pharmaceuticals $[27,28]$, nutraceuticals [29], biotechnology $[30,31]$, genetics $[32,33]$, medical [34] due to its astounding ability to alter the characteristic properties of the non-living and living objects. Scientific literature reported that The Trivedi Effect ${ }^{\circledR}$ - Energy of Consciousness Healing Treatment has the astounding capability to alter physicochemical properties such as crystalline structure, crystallite size, particle size, surface area, and thermal stability of magnesium gluconate after treatment with different healers
$[35,36]$. Hence, the current study was design to evaluate the impact of The Trivedi Effect ${ }^{\circledR}$ - Consciousness Energy Healing Treatment by Alice Branton on the physicochemical, and thermal properties of magnesium gluconate using various analytical techniques include powder X-ray diffraction (PXRD), particle size analysis (PSA), differential scanning calorimetry (DSC), and thermogravimetric analysis (TGA) analysis.

\section{Materials and Methods}

\subsection{Chemicals and Reagents}

Magnesium (II) gluconate hydrate was procured from Tokyo Chemical Industry Co., Ltd., Japan. All other chemicals used in the experiment were of analytical grade available in India.

\subsection{Energy of Consciousness Treatment Strategies}

The test compound, magnesium gluconate was divided into two parts. One part of the test compound did not receive the Biofield Energy Treatment and was considered as untreated or control magnesium gluconate. The second part of the test compound received the Energy of Consciousness Healing Treatment by the renowned Biofield Energy Healer, Alice Branton (USA), and designated as the Biofield Energy Treated magnesium gluconate. The Trivedi Effect ${ }^{\circledR}$ - Energy of Consciousness Healing Treatment was provided for 3 minutes through the Healer's Unique Energy Transmission process remotely to the test compound, which was kept under laboratory conditions. Similarly, the control compound was subjected to "sham" healer under the similar laboratory conditions. The sham healer did not have any knowledge about the Biofield Energy Treatment. After that, the Biofield Energy Treated and untreated samples were kept in similar sealed conditions and characterized using PXRD, PSA, DSC, and TGA techniques.

\subsection{Characterization}

\subsubsection{Powder X-ray Diffraction (PXRD) Analysis}

The PXRD analysis of magnesium gluconate was performed on a PANalytical X'Pert3 powder X-ray diffractometer, UK. Diffraction of the analyte was carried out using a copper line as the source of radiation at the X-ray of the wavelength of $0.154 \mathrm{~nm}$, running at $45 \mathrm{kV}$ voltage and 40 $\mathrm{mA}$ current with a scanning rate of $18.87^{\circ}$ /second over a $2 \theta$ range of $3-90^{\circ}$. The ratio of $\mathrm{K} \alpha-2$ and $\mathrm{K} \alpha-1$ in this instrument was 0.5 ( $\mathrm{k}$, equipment constant). The data was collected in the form of a chart of the Bragg angle $(2 \theta)$ vs. intensity (counts per second), and a detailed table containing information on peak intensity counts, d value $(\AA)$, relative intensity $(\%)$, full width half maximum (FWHM) $\left({ }^{\circ} 2 \theta\right)$, area (cts*02 ${ }^{*}$ ) using X'Pert data collector and X'Pert high score plus processing software. The crystallite size $(G)$ was calculated from the Scherrer equation following the literature [35-37]. The crystallite size $(G)$ was calculated by using the following equation 1 : 


$$
\mathrm{G}=\mathrm{k} \lambda /(\mathrm{b} \operatorname{Cos} \theta)
$$

Where, $\mathrm{k}$ is the equipment constant $(0.5), \lambda$ is the $\mathrm{X}$-ray wavelength $(0.154 \mathrm{~nm})$; $\mathrm{b}$ in radians is the full-width at half of the peaks and $\theta$ the corresponding Bragg angle.

Percent change in crystallite size $(G)$ of magnesium gluconate was calculated using following equation 2 :

$\%$ change in crystallite size $=\frac{\left[\mathrm{G}_{\text {Treated }}-\mathrm{G}_{\text {Control }}\right]}{\mathrm{G}_{\text {Control }}} \times 100$

Where, $G_{\text {Control }}$ and $G_{\text {Treated }}$ are the crystallite size of the control and Biofield Energy Treated samples, respectively.

\subsubsection{Particle Size Analysis (PSA)}

The particle size analysis of magnesium gluconate was conducted on Malvern Mastersizer 3000, UK with a detection range between $0.01 \mu \mathrm{m}$ to $3000 \mu \mathrm{m}$ using wet method [35-36]. The sample unit (Hydro MV) was filled with a dispersant medium (Light liquid paraffin oil) and operated the stirrer at $2500 \mathrm{rpm}$. Refractive index values for dispersant and samples were 0.0 and 1.47. The measurement was taken twice after reaching obscuration in between $10 \%$ and $20 \%$, and the average was taken of two measurements. Consequently, PSA analysis of magnesium gluconate was repeated for three times to obtain the average particle size distribution. $d_{10} \mu \mathrm{m}, d_{50} \mu \mathrm{m}, d_{90} \mu \mathrm{m}$ represent particle diameter corresponding to $10 \%, 50 \%$, and $90 \%$ of the cumulative distribution. $\mathrm{D}(4,3)$ represents the average massvolume diameter and specific surface area $\left(\mathrm{SSA}, \mathrm{m}^{2} / \mathrm{Kg}\right)$. The calculations were done by using software Mastersizer V3.50.

The percent change in particle size (d) for at below $10 \%$ level $\left(\mathrm{d}_{10}\right), 50 \%$ level $\left(\mathrm{d}_{50}\right)$, and $90 \%$ level $\left(\mathrm{d}_{90}\right)$ was calculated using following equation 3 :

$$
\% \text { change in particle size }=\frac{\left[\mathrm{d}_{\text {Treated }}-\mathrm{d}_{\text {Control }}\right]}{\mathrm{d}_{\text {Control }}} \times 100
$$

Where, $d_{\text {Control }}$ and $d_{\text {Treated }}$ are the particle size $(\mu \mathrm{m})$ for at below $10 \%$ level $\left(\mathrm{d}_{10}\right), 50 \%$ level $\left(\mathrm{d}_{50}\right)$, and $90 \%$ level $\left(\mathrm{d}_{90}\right)$ of the control and Biofield Energy Treated samples, respectively.

Percent change in surface area (S) was calculated using following equation 4 :

$$
\% \text { change in surface area }=\frac{\left[\mathrm{S}_{\text {Treated }}-\mathrm{S}_{\text {Control }}\right]}{\mathrm{S}_{\text {Control }}} \times 100
$$

Where, $\mathrm{S}_{\text {Control }}$ and $\mathrm{S}_{\text {Treated }}$ are the surface area of the control and Biofield Energy Treated magnesium gluconate, respectively.

\subsubsection{Differential Scanning Calorimetry (DSC)}

The DSC thermogram of magnesium gluconate was performed in DSC Q2000 differential scanning calorimeter, USA under the dynamic nitrogen atmosphere with flow rate of $50 \mathrm{~mL} / \mathrm{min}$ with a sample mass of $\sim 2.5 \mathrm{mg}$ using the aluminum pan at a heating rate of $10^{\circ} \mathrm{C} / \mathrm{min}$ from $30^{\circ} \mathrm{C}$ to $400^{\circ} \mathrm{C}[35,36]$. The $\%$ change in melting point (T) was calculated using following equation 5 :

$$
\% \text { change in melting point }=\frac{\left[\mathrm{T}_{\text {Treated }}-\mathrm{T}_{\text {Control }}\right]}{\mathrm{T}_{\text {Control }}} \times 100
$$

Where, $\mathrm{T}_{\text {Control }}$ and $\mathrm{T}_{\text {Treated }}$ are the melting point of the control and treated samples, respectively.

Percent change in the latent heat of fusion $(\Delta \mathrm{H})$ was calculated using following equation 6 :

$$
\% \text { change in latent heat of fusion }=\frac{\left[\Delta \mathrm{H}_{\text {Treated }}-\Delta \mathrm{H}_{\text {Control }}\right]}{\Delta \mathrm{H}_{\text {Control }}} \times 100
$$

Where, $\Delta \mathrm{H}_{\text {Control }}$ and $\Delta \mathrm{H}_{\text {Treated }}$ are the latent heat of fusion of the control and treated magnesium gluconate, respectively.

\subsubsection{Thermal Gravimetric Analysis (TGA) / Differential Thermogravimetric Analysis (DTG)}

TGA/DTG thermograms of magnesium gluconate were obtained in a TGA Q500 themoanalyzer apparatus, USA under the dynamic nitrogen atmosphere $(50 \mathrm{~mL} / \mathrm{min})$ using a platinum crucible at a heating rate of $10^{\circ} \mathrm{C} / \mathrm{min}$ from $25^{\circ} \mathrm{C}$ to $900^{\circ} \mathrm{C}$ with the recent literature $[35,36]$. The $\%$ change in weight loss (W) was calculated using following equation 7 :

$$
\% \text { change in weight loss }=\frac{\left[\mathrm{W}_{\text {Treated }}-\mathrm{W}_{\text {Control }}\right]}{\mathrm{w}_{\text {Control }}} \times 100
$$

Where, $\mathrm{W}_{\text {Control }}$ and $\mathrm{W}_{\text {Treated }}$ are the weight loss of the control and Biofield Energy Treated magnesium gluconate, respectively.

The $\%$ change in maximum thermal degradation temperature $\left(\mathrm{T}_{\max }\right)(\mathrm{M})$ was calculated using following equation 7:

$$
\% \text { change in } \mathrm{T}_{\max }(\mathrm{M})=\frac{\left[\mathrm{M}_{\text {Treated }}-\mathrm{M}_{\text {Control }}\right]}{\mathrm{M}_{\text {Control }}} \times 100
$$

Where, $\mathrm{M}_{\text {Control }}$ and $\mathrm{M}_{\text {Treated }}$ are the $\mathrm{T}_{\max }$ values of the control and Biofield Energy Treated ferrous sulphate, respectively.

\section{Results and Discussion}

\subsection{Powder X-ray Diffraction (PXRD) Analysis}

The PXRD diffractograms of both the control and Biofield Energy Treated magnesium gluconate exhibited sharp and intense peaks (Figure 1) indicating that both the samples were crystalline in nature. PXRD data such as the Bragg angle $(2 \theta)$, relative intensity $(\%)$, and crystallite size $(G)$ for the control and Biofield Energy Treated magnesium gluconate are presented in Table 1.

The highest intense peak (100\% relative intensity) in the control and Biofield Energy Treated samples was observed at Bragg's angle (20) equal to $19.0^{\circ}$ and $5.1^{\circ}$, respectively 
(Table 1, entry 1 and 10). Table 1 showed that Bragg's angle

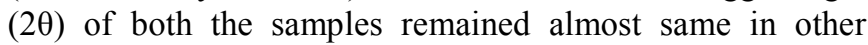
PXRD peaks, but the relative intensities of the peaks of the Biofield Energy Treated sample was found different from the control sample. Thus, relative peak intensities of the Biofield Energy Treated magnesium gluconate was significantly altered in the range of $-73.55 \%$ to $17.21 \%$. However, the overall intensity of characteristic diffraction peaks weakened after the Alice's Biofield Energy Treatment. The crystallite sizes of the control and Biofield Energy Treated magnesium gluconate at position $2 \theta$ equal to nearly $10.70^{\circ}, 13.9^{\circ}, 20.1^{\circ}$, $20.9^{\circ}, 22.4^{\circ}$, and $40.4^{\circ}$ (Table 1 , entry $3,4,12,14,15$, and 26) remained unchanged. But, the crystallite size values of the Biofield Energy Treated sample at $2 \theta$ equal to nearly $15.3^{\circ}, 15.8^{\circ}, 16.4^{\circ}, 17.9^{\circ}, 18.5^{\circ}, 19.0^{\circ}, 19.8^{\circ}, 20.4^{\circ}, 23.6^{\circ}$, $24.7^{\circ}, 27.04^{\circ}, 29.0^{\circ}, 31.4^{\circ}, 32.5^{\circ}$, and $39.6^{\circ}$ (Table 1 , entry $5-11,13,16,17,19,20,22,23$, and 25) were significantly increased from $10.01 \%$ to $125.11 \%$ with respect to the control sample. Consequently, the crystallite sizes of the Biofield Energy Treated sample at $2 \theta$ equal to $5.1^{\circ}, 9.9^{\circ}$, $25.6^{\circ}$, and $35.8^{\circ}$ (Table 1 , entry $1,2,18$, and 24) were significantly decreased from $6.67 \%$ to $14.28 \%$ compared to the control sample. The average crystallite size of the Biofield Energy Treated magnesium gluconate was significantly increased by $19.29 \%$ compared with the control sample. As per the literature, the changes in the PXRD patterns such as crystallite size and relative intensities, indicated the modification of the morphology of the crystal as well as the proof of polymorphic transition [38-40]. As the crystallite size of the Biofield Energy Treated sample was significantly altered compared with the control sample, which might produce a new polymorphic form of magnesium gluconate. Polymorphic forms of pharmaceutical solids have the significant impact on the drug performance, such as bioavailability, therapeutic efficacy, and toxicity, because their thermodynamic and physicochemical properties like melting point, energy, stability, and especially solubility, are different (probably improvement) from the original form [39, 40]. Thus, it can be anticipated that Alice's Biofield Energy Treatment could be a very useful approach for the production of novel crystal polymorph of magnesium gluconate that would provide an improvement on its therapeutic performance [41].

Table 1. PXRD data for the control and Biofield Energy Treated magnesium gluconate.

\begin{tabular}{|c|c|c|c|c|c|c|c|}
\hline \multirow{2}{*}{ Entry No. } & \multirow{2}{*}{$\begin{array}{l}\text { Bragg } \\
\text { angle }\left({ }^{\circ} 2 \theta\right)\end{array}$} & \multicolumn{3}{|c|}{ Relative Intensity (\%) } & \multicolumn{3}{|c|}{ Crystallite size (G, $\mathrm{nm})$} \\
\hline & & Control & Treated & $\%$ change $^{a}$ & Control & Treated & $\%^{\circ}$ change $^{b}$ \\
\hline 1 & 5.1 & 85.32 & 100.00 & 17.21 & 48.95 & 43.07 & -12.02 \\
\hline 2 & 9.9 & 38.67 & 29.11 & -24.72 & 43.19 & 38.38 & -11.12 \\
\hline 3 & 10.7 & 18.50 & 5.48 & -70.38 & 38.41 & 38.41 & 0.00 \\
\hline 4 & 13.9 & 49.41 & 32.91 & -33.39 & 31.51 & 31.51 & 0.00 \\
\hline 5 & 15.3 & 10.93 & 4.81 & -55.99 & 34.72 & 49.62 & 42.90 \\
\hline 6 & 15.8 & 26.1 & 19.43 & -25.56 & 34.75 & 38.61 & 11.12 \\
\hline 7 & 16.4 & 16.85 & 12.81 & -23.98 & 27.23 & 31.61 & 16.06 \\
\hline 8 & 17.9 & 94.81 & 33.23 & -64.95 & 26.80 & 49.79 & 85.78 \\
\hline 9 & 18.5 & 77.96 & 61.51 & -21.10 & 31.70 & 34.87 & 10.01 \\
\hline 10 & 19.0 & 100.00 & 38.64 & -61.36 & 23.26 & 26.84 & 15.38 \\
\hline 11 & 19.8 & 20.08 & 8.33 & -58.52 & 34.93 & 38.82 & 11.12 \\
\hline 12 & 20.1 & 15.67 & 12.72 & -18.83 & 34.95 & 34.95 & 0.00 \\
\hline 13 & 20.4 & 29.72 & 7.86 & -73.55 & 34.97 & 49.97 & 42.90 \\
\hline 14 & 20.9 & 23.87 & 20.09 & -15.84 & 26.92 & 26.92 & 0.00 \\
\hline 15 & 22.4 & 33.64 & 28.66 & -14.80 & 29.23 & 29.23 & 0.00 \\
\hline 16 & 23.6 & 43.84 & 28.37 & -35.29 & 15.98 & 29.30 & 83.34 \\
\hline 17 & 24.7 & 17.98 & 11.49 & -36.10 & 19.57 & 44.05 & 125.11 \\
\hline 18 & 25.6 & 21.74 & 8.13 & -62.60 & 29.40 & 25.20 & -14.28 \\
\hline 19 & 27.4 & 29.44 & 19.1 & -35.12 & 13.62 & 27.24 & 100.00 \\
\hline 20 & 29.0 & 27.37 & 8.95 & -67.30 & 25.39 & 29.62 & 16.67 \\
\hline 21 & 29.3 & 20.76 & 16.53 & -20.38 & 35.58 & 35.58 & -0.01 \\
\hline 22 & 31.4 & 15.35 & 10.25 & -33.22 & 16.25 & 32.50 & 100.00 \\
\hline 23 & 32.5 & 14.8 & 5.71 & -61.42 & 23.89 & 29.87 & 25.01 \\
\hline 24 & 35.8 & 15.12 & 11.08 & -26.72 & 25.83 & 24.11 & -6.67 \\
\hline 25 & 39.6 & 13.93 & 10.2 & -26.78 & 28.14 & 45.75 & 62.56 \\
\hline 26 & 40.4 & 16.02 & 12.02 & -24.97 & 45.86 & 45.86 & 0.00 \\
\hline
\end{tabular}

${ }^{a}$ denotes the percentage change in the relative intensity of Biofield Energy Treated sample with respect to the control sample; benotes the percentage change in the crystallite size of Biofield Energy Treated sample with respect to the control sample. 

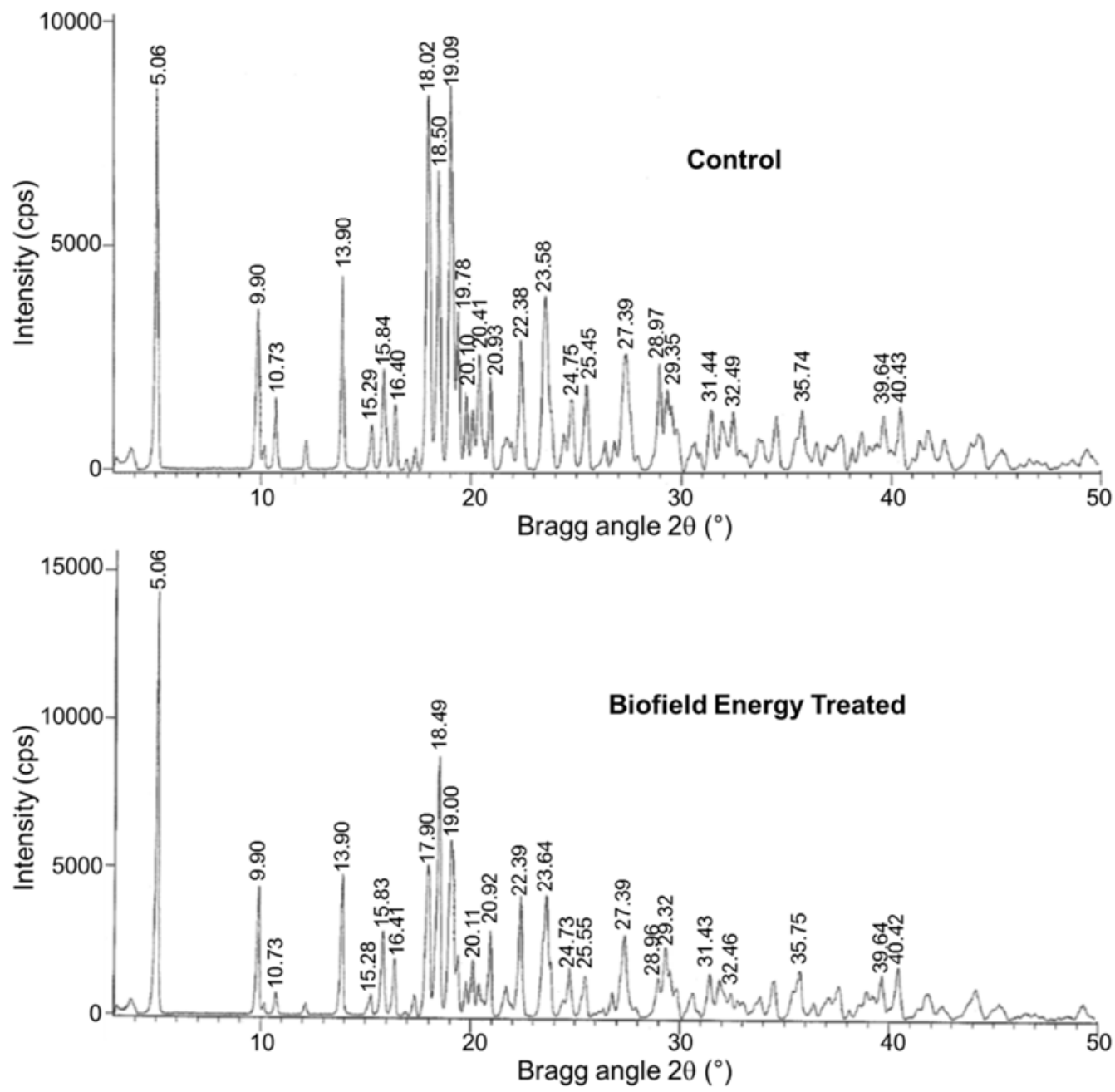

Figure 1. Powder X-ray diffractograms of the control and Biofield Energy Treated magnesium gluconate.

\subsection{Particle Size Analysis (PSA)}

The particle size and surface area of the control and Biofield Energy Treated magnesium gluconate was calculated and presented in Table 2. The particle size distribution of the control sample was observed at $\mathrm{d}_{10}(10.83$ $\mu \mathrm{m}), \mathrm{d}_{50}(25.34 \mu \mathrm{m}), \mathrm{d}_{90}(79.29 \mu \mathrm{m})$, and $\mathrm{D}(4,3)(38.86 \mu \mathrm{m})$. Consequently, the particle size distribution of the Biofield Energy Treated sample was found at $\mathrm{d}_{10}(11.05 \mu \mathrm{m}), \mathrm{d}_{50}$
(43.31 $\mu \mathrm{m}), \mathrm{d}_{90}(192.08 \mu \mathrm{m})$, and $\mathrm{D}(4,3)(75.94 \mu \mathrm{m})$. The particle size values at $\mathrm{d}_{10}, \mathrm{~d}_{50}, \mathrm{~d}_{90}$, and $\mathrm{D}(4,3)$ in Alice's Biofield Energy Treated magnesium gluconate was significantly increased by $2.03 \%, 70.92 \%, 142.25 \%$, and $95.42 \%$, respectively compared with the control sample. Therefore, the specific surface area (SSA) of Biofield Energy Treated magnesium gluconate $\left(268.00 \quad \mathrm{~m}^{2} / \mathrm{Kg}\right)$ was significantly decreased by $21.34 \%$ with respect to the control sample $\left(210.80 \mathrm{~m}^{2} / \mathrm{Kg}\right)$.

Table 2. Particle size distribution of the control and Biofield Energy Treated magnesium gluconate.

\begin{tabular}{|c|c|c|c|c|c|}
\hline Test Item & $d_{10}(\mu \mathrm{m})$ & $d_{50}(\mu \mathrm{m})$ & $d_{90}(\mu \mathrm{m})$ & $\mathrm{d}(4,3)(\mu \mathrm{m})$ & $\mathrm{SSA}\left(\mathrm{m}^{2} / \mathrm{Kg}\right)$ \\
\hline Control & 10.83 & 25.34 & 79.29 & 38.86 & 268.00 \\
\hline Biofield Energy Treated & 11.05 & 43.31 & 192.08 & 75.94 & 210.80 \\
\hline Percent change ${ }^{*}(\%)$ & 2.03 & 70.92 & 142.25 & 95.42 & -21.34 \\
\hline
\end{tabular}

$\mathrm{d}_{10}, \mathrm{~d}_{50}$, and $\mathrm{d}_{90}$ : particle diameter corresponding to $10 \%, 50 \%$, and $90 \%$ of the cumulative distribution, $\mathrm{D}(4,3)$ : the average mass-volume diameter, and SSA: the specific surface area; ${ }^{*}$ denotes the percentage change in the Particle size distribution of the Biofield Energy Treated sample with respect to the control sample.

The particle size and surface area of a pharmaceutical solid compound play a vital role in the solubility, absorption, dissolution rate and bioavailability $[42,43]$. The introduction of the Biofield Energy leads to the transform the fine particles into larger particles. The increased the particle size may enhance the flowability with improved product shape and appearance $[44,45]$. It is assumed that The Trivedi Effect $^{\circledR}$ - Energy of Consciousness Healing Treatment might improve the flowability, shape, and appearance of magnesium gluconate. 


\subsection{Differential Scanning Calorimetry (DSC) Analysis}

The DSC thermograms of the control and Biofield Energy
Treated magnesium gluconate (Figure 2) exhibited two endothermic peaks. The first endothermic peak (minor) was due to the evaporation of the water from the sample.
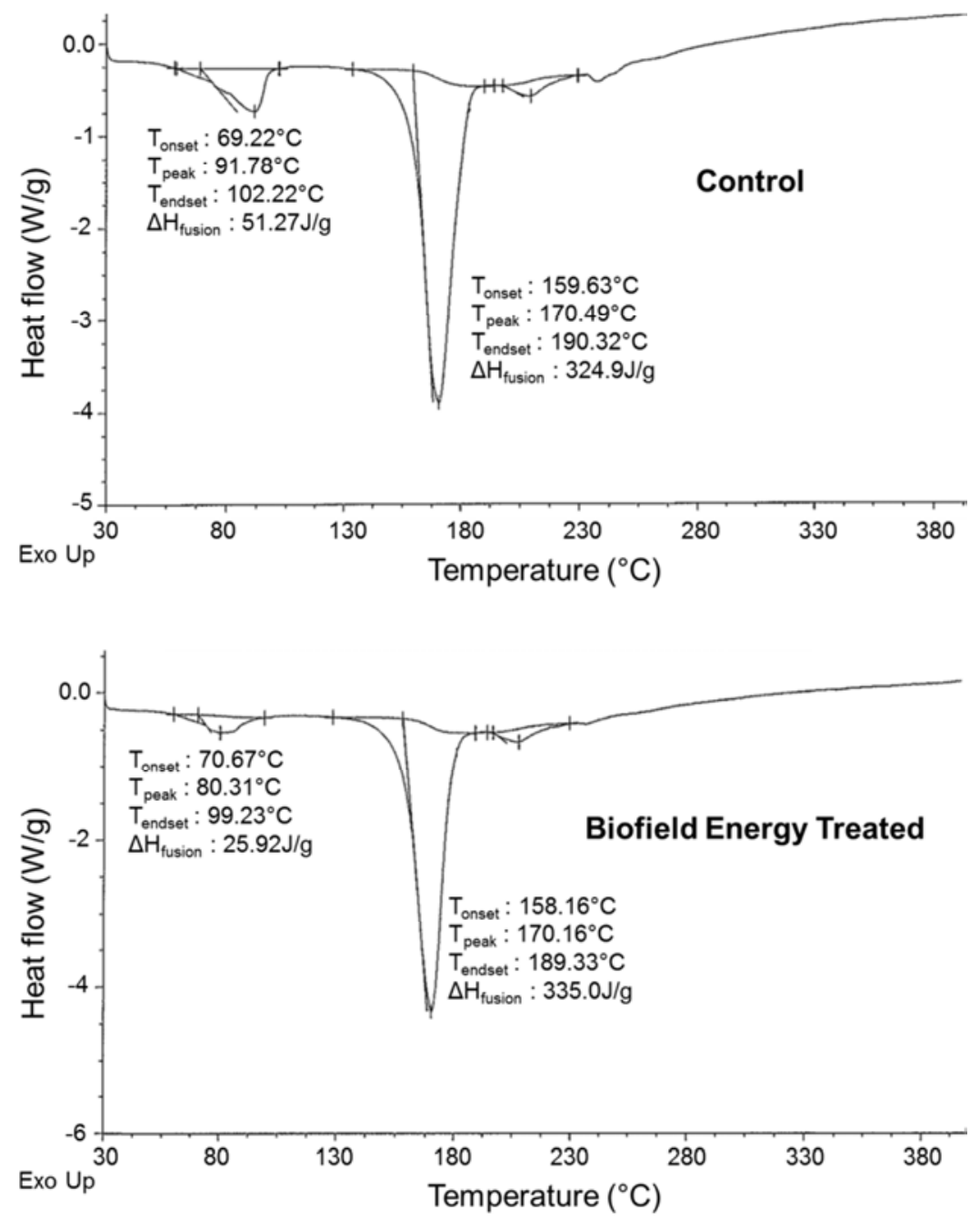

Figure 2. DSC thermograms of the control and Biofield Energy Treated magnesium gluconate.

Table 3. The latent heat of fusion $(\mathrm{J} / G)$ and melting point $\left({ }^{\circ} \mathrm{C}\right)$ values of the control and Biofield Energy Treated magnesium gluconate.

\begin{tabular}{llll}
\hline Peak & Description & Melting Point $\left({ }^{\circ} \mathbf{C}\right)$ & $\Delta \mathbf{H}_{\text {fusion }}(\mathbf{J} / \mathbf{g})$ \\
\hline \multirow{3}{*}{ Peak 1 (Minor) } & Control sample & 91.78 & 51.27 \\
& Biofield Treated sample & 80.31 & 25.92 \\
& \% Change & -12.50 & -49.44 \\
\multirow{2}{*}{ Peak 2 (Major) } & Control sample & 170.48 & 324.90 \\
& Biofield Treated sample $^{\text {\% Change }}$ & 170.16 & 335.00 \\
\hline
\end{tabular}

$\Delta \mathrm{H}_{\text {fusion: }}$ Latent heat of fusion; "denotes the percentage change of the Biofield Energy Treated sample with respect to the control sample.

The second sharp endothermic peak (major) was due to the melting temperature of the magnesium gluconate (Figure 2). The vaporization temperature and latent heat of vaporization were significantly decrease by $12.50 \%$ and $49.44 \%$, respectively (Table 3 ). The melting temperature of the Biofield Energy Treated magnesium gluconate $\left(170.48^{\circ} \mathrm{C}\right)$ was almost closer the control sample $\left(170.16^{\circ} \mathrm{C}\right)$, but the latent heat of fusion $\left(\Delta \mathrm{H}_{\text {fusion }}\right)$ in the Biofield Energy Treated magnesium gluconate was increased by $3.11 \%$ compared to the control sample (Table 3). An increment in the particle size increases the melting point and latent heat of fusion [46]. The DSC results were well supported by the particle size data and suggested that the thermal stability of Alice's Biofield Energy Treated magnesium gluconate was increased compared with the control sample.

\subsection{Thermal Gravimetric Analysis (TGA) / Differential Thermogravimetric Analysis (DTG)}

The TGA study of the control and the Biofield Energy 
Treated magnesium gluconate exhibited three thermal degradation steps (Figure 3), and the data are presented in Table 4. The weight loss of the Biofield Energy Treated sample at the $1^{\text {st }}$ steps of thermal degradation was decreased by $5.93 \%$ compared to the control sample. Whereas, the weight loss of the Biofield Energy Treated magnesium
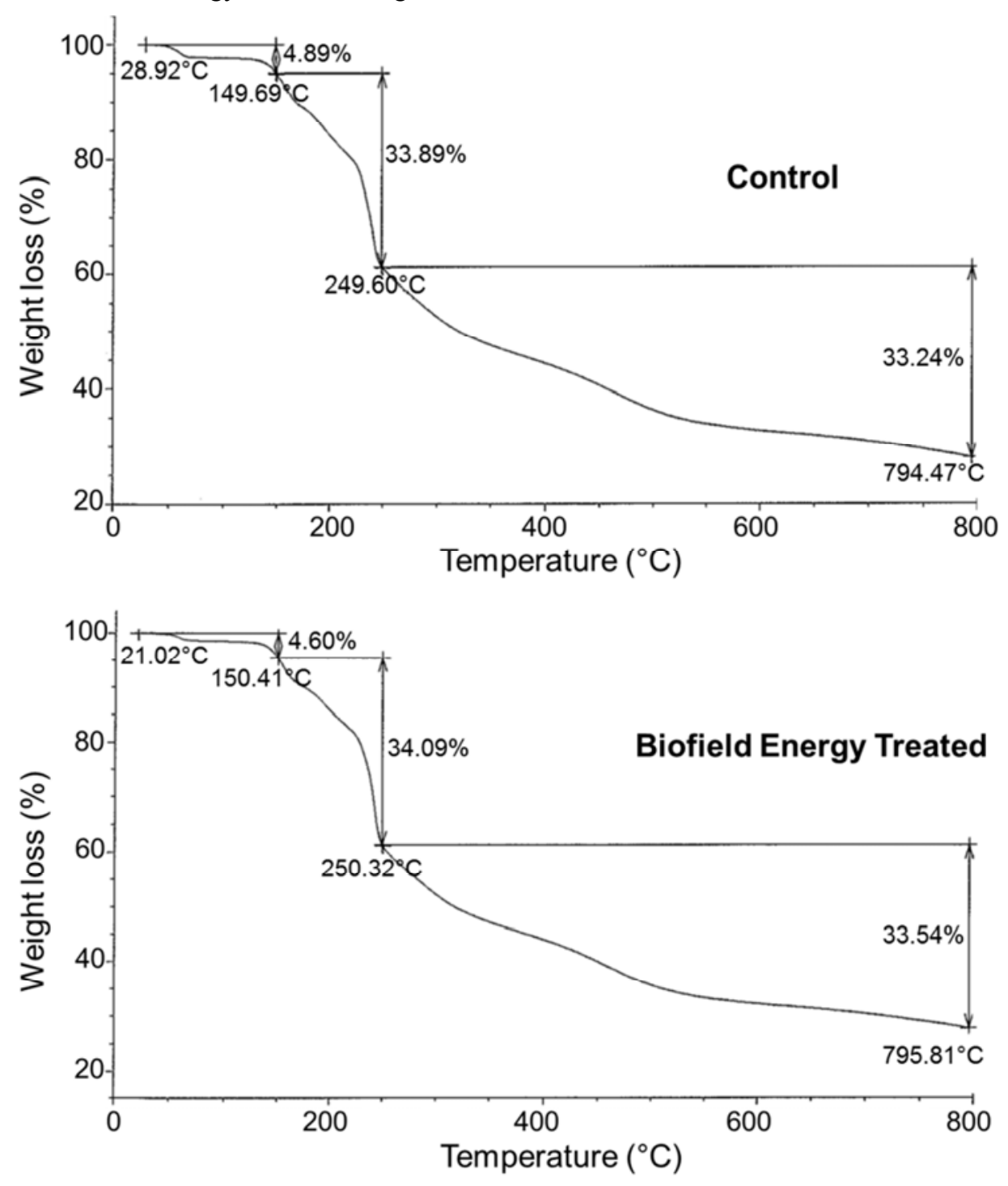

Figure 3. The TGA thermograms of the control and Biofield Energy Treated magnesium gluconate.

Table 4. The TGA thermal degradation steps of the control and Biofield Energy Treated magnesium gluconate.

\begin{tabular}{|c|c|c|c|c|}
\hline \multirow{2}{*}{ Sample } & \multicolumn{4}{|c|}{ TGA Weight loss (\%) } \\
\hline & $1^{\text {st }}$ step & $2^{\text {nd }}$ step & $3^{\text {rd }}$ step & Total \\
\hline Control Sample & 4.89 & 33.89 & 33.24 & 72.02 \\
\hline Biofield Energy Treated Sample & 4.6 & 34.09 & 33.54 & 72.23 \\
\hline$\%$ Change $^{*}$ & -5.93 & 0.59 & 0.90 & 0.29 \\
\hline
\end{tabular}

${ }^{*}$ denotes the percentage change in the weight loss of the Biofield Energy Treated sample with respect to the control sample.

The DTG thermograms of the control and Biofield Energy Treated samples (Figure 4) exhibited four peaks. The maximum thermal degradation temperature $\left(\mathrm{T}_{\max }\right)$ of $1^{\text {st }}$ and $2^{\text {nd }}$ peaks of the Biofield Energy Treated sample were decreased by $2.86 \%$ and $1.97 \%$, respectively compared to the control sample (Table 5). The $\mathrm{T}_{\max }$ of $3^{\text {rd }}$ and $4^{\text {th }}$ peaks in the
Biofield Energy Treated sample were increased by $1.14 \%$ and $0.94 \%$, respectively compare to the control sample (Table 5). Overall, TGA/DTG revealed that the thermal stability of the Alice's Biofield Energy Treated magnesium gluconate was altered compared to the control sample. 

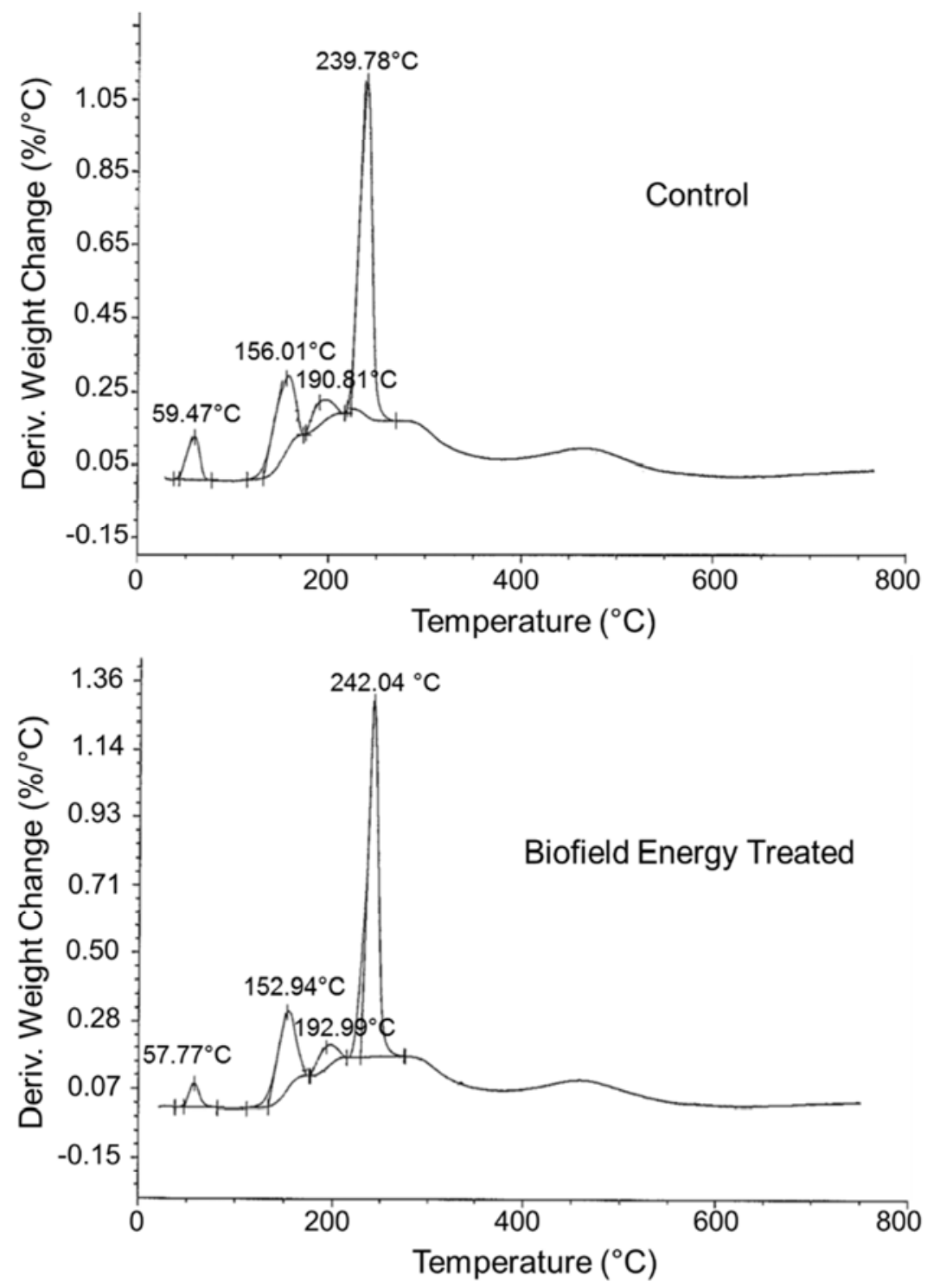

Figure 4. The DTG thermograms of the control and Biofield Energy Treated magnesium gluconate.

Table 5. The DTG thermal degradation steps of the control and Biofield Energy Treated magnesium gluconate.

\begin{tabular}{llll}
\hline \multirow{2}{*}{ Sample } & \multicolumn{3}{c}{$\mathbf{T}_{\max }\left({ }^{\circ} \mathbf{C}\right)$} \\
\cline { 2 - 4 } & $\mathbf{1}^{\text {st }}$ step & $\mathbf{2}^{\text {nd }}$ step & $\mathbf{3}^{\text {rd }}$ step \\
\hline Control Sample & 59.47 & 156.01 & 190.81 \\
Biofield Energy Treated Sample & 57.77 & 152.94 & 239.78 \\
\% Change $^{*}$ & -2.86 & -1.97 & 192.99 \\
\hline
\end{tabular}

${ }^{*}$ denotes the percentage change in the weight loss of the Biofield Energy Treated sample with respect to the control sample, $\mathrm{T}_{\max }=$ the temperature at which maximum weight loss takes place in TG or peak temperature in DTA.

\section{Conclusions}

The Trivedi Effect ${ }^{\circledR}$ - Energy of Consciousness Healing Treatment exhibited significant effects on the physicochemical and thermal properties of magnesium gluconate. The sharp and intense peaks in the PXRD diffractograms of the control and treated magnesium gluconate revealed that both the samples were crystalline in nature. The relative peak intensities of the characteristic diffraction peaks in the treated sample were significantly altered from $-73.55 \%$ to $17.21 \%$. Similarly, the crystallite size of the characteristic diffraction peaks in the treated sample was significantly altered from $-14.28 \%$ to $125.11 \%$ compared to the control sample. The average crystallite size was significantly increased by $19.29 \%$ in the treated sample compared with the control sample. The particle size values at $\mathrm{d}_{10}, \mathrm{~d}_{50}, \mathrm{~d}_{90}$, and $\mathrm{D}(4,3)$ in Alice's treated magnesium gluconate was significantly increased by $2.03 \%, 70.92 \%$, $142.25 \%$, and $95.42 \%$, respectively compared with the 
control sample. The surface area of treated magnesium gluconate was significantly decreased by $21.34 \%$ with respect to the control sample. The melting point of the Biofield Energy Treated sample $\left(170.16^{\circ} \mathrm{C}\right)$ was lowered by $0.19 \%$ compared the control sample $\left(170.48^{\circ} \mathrm{C}\right)$. The latent heat of fusion in the Biofield Energy treated magnesium gluconate was increased by $3.11 \%$ compared to the control sample. The TGA analysis exhibited three steps thermal degradation in both samples. The total weight loss of the treated sample was increased by $0.29 \%$ to the control sample. The maximum thermal degradation temperatures $\left(\mathrm{T}_{\max }\right)$ of the first two peaks were decreased by $2.86 \%$ and $1.97 \%$, respectively, while 2 nd and 3 rd peaks were increased by $1.14 \%$ and $0.94 \%$, respectively in the treated sample compared to the control sample. The DSC and TGA/DTG analysis revealed that the thermal stability of the treated sample was altered compared with the control sample. The Energy of Consciousness Healing Treatment might produce a polymorphic form of magnesium gluconate, which could show better powder flowability and appearance with altered thermal stability compared to the untreated sample. Thus, The Alice's Energy of Consciousness Healing Treated magnesium gluconate would be very useful to design better nutraceutical and pharmaceutical formulations for the treatment of cancer, diabetes mellitus, allergies, septic shock, inflammatory diseases, immunological disorders, asthma, arrhythmias, acute myocardial infarction, gestational hypertension, preeclampsia, eclampsia, hearing loss, oxidative stress induced ischemia/reperfusion injury, etc.

\section{Acknowledgements}

The authors are grateful to GVK Biosciences Pvt. Ltd., Trivedi Science, Trivedi Global, Inc., and Trivedi Master Wellness for their assistance and support during this work.

\section{References}

[1] Heaton FW (1990) Role of magnesium in enzyme systems in metal ions in biological systems, In: Sigel H, Sigel A (Eds.), Volume 26: Compendium on magnesium and its role in biology, nutrition and physiology, Marcel Dekker Inc., New York.

[2] Frick DN, Banik S, Rypma RS (2007) Role of divalent metal cations in ATP hydrolysis catalyzed by the hepatitis $\mathrm{C}$ virus NS3 helicase: Magnesium provides a bridge for ATP to fuel unwinding. J Mol Biol 365: 1017-1032.

[3] Garfinkel L, Garfinkel D (1985) Magnesium regulation of the glycolytic pathway and the enzymes involved. Magnesium 4: 60-72.

[4] Fleming TE, Mansmann Jr HC (1999) Methods and compositions for the prevention and treatment of immunological disorders, inflammatory diseases and infections. United States Patent 5939394, 1-11.

[5] Fleming TE, Mansmann Jr HC (1999) Methods and compositions for the prevention and treatment of diabetes mellitus. United States Patent 5871769, 1-10.
[6] Guerrera MP, Volpe SL, Mao JJ (2009) Therapeutic uses of magnesium. Am Fam Physician 80: 157-162.

[7] Gums JG (2004) Magnesium in cardiovascular and other disorders. Am J Health Syst Pharm 61: 1569-1576.

[8] Gröber U, Schmidt J, Kisters K (2015) Magnesium in prevention and therapy. Nutrients 7: 8199-8226.

[9] Weglicki WB (2000) Intravenous magnesium gluconate for treatment of conditions caused by excessive oxidative stress due to free radical distribution. United States Patent 6100297, $1-6$.

[10] Clague JE, Edwards RH, Jackson MJ (1992) Intravenous magnesium loading in chronic fatigue syndrome. Lancet 340: 124-125.

[11] Martin RW, Martin JN Jr, Pryor JA, Gaddy DK, Wiser WL, Morrison JC (1988) Comparison of oral ritodrine and magnesium gluconate for ambulatory tocolysis. Am J Obstet Gynecol 158: 1440-1445.

[12] Turner RJ, Dasilva KW, O'Connor C, van den Heuvel C, Vink R (2004) Magnesium gluconate offers no more protection than magnesium sulphate following diffuse trau-matic braininjury in rats. J Am Coll Nutr 23: 541S-544S.

[13] Lee KH, Chung SH, Song JH, Yoon JS, Lee J, Jung MJ, Kim JH (2013) Cosmetic compositions for skin-tightening and method of skin-tightening using the same. United States Patent 8580741 B2.

[14] Coudray C, Rambeau M, Feillet-Coudray C, Gueux E, Tressol JC, Mazur A, Rayssiguier Y (2005) Study of magnesium bioavailability from ten organic and inorganic $\mathrm{Mg}$ salts in $\mathrm{Mg}$ depleted rats using a stable isotope approach. Magnes Res 18: 215-223.

[15] Stenger VJ (1999) Bioenergetic fields. Sci Rev Alternative Med 3.

[16] Warber SL, Cornelio D, Straughn J, Kile G (2004) Biofield energy healing from the inside. J Altern Complement Med 10: 1107-1113.

[17] Rubik B (2002) The biofield hypothesis: Its biophysical basis and role in medicine. J Altern Complement Med 8: 703-717.

[18] Koithan M (2009) Introducing complementary and alternative therapies. J Nurse Pract 5: 18-20.

[19] Trivedi MK, Tallapragada RM, Branton A, Trivedi D, Nayak G, Latiyal O, Jana S (2015) Evaluation of physical and structural properties of biofield energy treated barium calcium tungsten oxide. Advances in Materials 4: 95-100.

[20] Trivedi MK, Nayak G, Patil S, Tallapragada RM, Latiyal O, Jana S (2015) Impact of biofield treatment on atomic and structural characteristics of barium titanate powder. Ind Eng Manage 4: 166.

[21] Trivedi MK, Branton A, Trivedi D, Nayak G, Singh R, Jana S (2015) Characterization of physical, thermal and spectroscopic properties of biofield energy treated $p$-phenylenediamine and $p$-toluidine. J Environ Anal Toxicol 5: 329.

[22] Trivedi MK, Branton A, Trivedi D, Nayak G, Singh R, Jana S (2015) Characterization of biofield energy treated 3chloronitrobenzene: Physical, thermal, and spectroscopic studies. J Waste Resources 5: 183. 
[23] Trivedi MK, Branton A, Trivedi D, Nayak G, Mondal SC, Jana S (2015) Evaluation of biochemical marker glutathione and DNA fingerprinting of biofield energy treated Oryza sativa. American Journal of BioScience 3: 243-248.

[24] Trivedi MK, Branton A, Trivedi D, Nayak G, Mondal SC, Jana S (2015) Morphological characterization, quality, yield and DNA fingerprinting of biofield energy treated alphonso mango (Mangifera indica L.). Journal of Food and Nutrition Sciences 3: 245-250.

[25] Trivedi MK, Patil S, Shettigar H, Mondal SC, Jana S (2015) Evaluation of biofield modality on viral load of Hepatitis B and $\mathrm{C}$ viruses. J Antivir Antiretrovir 7: 083-088.

[26] Trivedi MK, Branton A, Trivedi D, Nayak G, Bairwa K, Jana S (2015) In vitro evaluation of antifungal sensitivity assay of biofield energy treated fungi. Fungal Genom Biol 5: 125.

[27] Trivedi MK, Branton A, Trivedi D, Shettigar H, Bairwa K, Jana S (2015) Fourier transform infrared and ultravioletvisible spectroscopic characterization of biofield treated salicylic acid and sparfloxacin. Nat Prod Chem Res 3: 186.

[28] Trivedi MK, Branton A, Trivedi D, Nayak G, Bairwa K, Jana S (2015) Spectroscopic characterization of disulfiram and nicotinic acid after biofield treatment. J Anal Bioanal Tech 6: 265.

[29] Trivedi MK, Tallapragada RM, Branton A, Trivedi D, Nayak G, Latiyal O, Mishra RK, Jana S (2015) Physicochemical characterization of biofield energy treated calcium carbonate powder. American Journal of Health Research 3: 368-375.

[30] Trivedi MK, Patil S, Shettigar H, Bairwa K, Jana S (2015) Evaluation of phenotyping and genotyping characteristic of Shigella sonnei after biofield treatment. J Biotechnol Biomater 5: 196.

[31] Trivedi MK, Branton A, Trivedi D, Nayak G, Gangwar M, Jana S (2015) Bacterial identification using 16S rDNA gene sequencing and antibiogram analysis on biofield treated Pseudomonas fluorescens. Clin Med Biochemistry Open Access 1: 101.

[32] Trivedi MK, Branton A, Trivedi D, Nayak G, Gangwar M, Jana S (2015) Characterization of phenotype and genotype of biofield treated Enterobacter aerogenes. Transl Med 5: 155 .

[33] Trivedi MK, Branton A, Trivedi D, Shettigar H, Nayak G, Mondal SC, Jana S (2015) Phenotyping and genotyping characterization of Proteus vulgaris after biofield treatment. International Journal of Genetics and Genomics 3: 66-73.

[34] Trivedi MK, Patil S, Shettigar H, Mondal SC, Jana S (2015) The potential impact of biofield treatment on human brain tumor cells: A time-lapse video microscopy. J Integr Oncol 4: 141.
[35] Trivedi MK, Branton A, Trivedi D, Nayak G, Plikerd WD, Surguy PL, Kock RJ, Piedad RB, Callas RP, Ansari SA, Barrett SL, Friedman S, Christie SL, Chen Liu S-M, Starling SE, Jones S, Allen SM, Wasmus SK, Benczik TA, Slade TC, Orban T, Vannes VL, Schlosser VM, Albino YSY, Panda P, Sethi KK, Jana S (2017). A systematic study of the biofield energy healing treatment on physicochemical, thermal, structural, and behavioral properties of magnesium gluconate. International Journal of Bioorganic Chemistry. 2: 135-145.

[36] Trivedi MK, Branton A, Trivedi D, Nayak G, Wellborn BD, Smith DL, Koster DA, Patric E, Singh J, Vagt KS, Callas KJ, Panda P, Sethi KK, Jana S (2017) Characterization of physicochemical, thermal, structural, and behavioral properties of magnesium gluconate after treatment with the Energy of Consciousness. International Journal of Pharmacy and Chemistry $3: 1-12$.

[37] Langford JI, Wilson AJC (1978) Scherrer after sixty years: A survey and some new results in the determination of crystallite size. J Appl Cryst 11: 102-113.

[38] Inoue M, Hirasawa I (2013) The relationship between crystal morphology and XRD peak intensity on $\mathrm{CaSO}_{4} \cdot 2 \mathrm{H}_{2} \mathrm{O}$. J Crystal Growth 380: 169-175.

[39] Raza K, Kumar P, Ratan S, Malik R, Arora S (2014) Polymorphism: The phenomenon affecting the performance of drugs. SOJ Pharm Pharm Sci 1: 10.

[40] Brittain HG (2009) Polymorphism in pharmaceutical solids in Drugs and Pharmaceutical Sciences, volume 192, $2^{\text {nd }}$ Edn, Informa Healthcare USA, Inc., New York.

[41] Censi R, Martino PD (2015) Polymorph Impact on the Bioavailability and Stability of Poorly Soluble Drugs. Molecules 20: 18759-18776.

[42] Chereson R (2009) Bioavailability, bioequivalence, and drug selection. In: Makoid CM, Vuchetich PJ, Banakar UV (Eds) Basic pharmacokinetics ( $1^{\text {st }}$ Edn) Pharmaceutical Press, London.

[43] Khadka P, Ro J, Kim H, Kim I, Kim JT, Kim H, Cho JM, Yun G, Lee J (2014) Pharmaceutical particle technologies: An approach to improve drug solubility, dissolution and bioavailability. Asian J Pharm Sci 9: 304-316.

[44] Kale VV, Gadekar S, Ittadwar AM (2011) Particle size enlargement: Making and understanding of the behavior of powder (particle) system. Syst Rev Pharm 2: 79.

[45] Podczeck F, Mia Y (1996) The influence of particle size and shape on the angle of internal friction and the flow factor of unlubricated and lubricated powders. Int J Pharm 144: 187194.

[46] Zhang M, Efremov MY, Schiettekatte F, Olson EA, Kwan AT, Lai SL, Wisleder T, Greene JE, Allen LH (2000) Sizedependent melting point depression of nanostructures: Nanocalorimetric measurements. Phys Rev B 62: 10548. 